\title{
Interpretations of New Diplomatic Thoughts in the Report of the 18th National Congress of the Communist Party of China
}

\author{
Yang Yang ${ }^{1}$ \\ ${ }^{1}$ School of Political Science and Public Management, Southwest University, Chongqing, China \\ Correspondence: Yang Yang, School of Political Science and Public Management, Southwest University, \\ Chongqing, China. E-mail: yangyhao@163.com
}

Received: January 22, 2014 Accepted: February 10, 2014 Online Published: February 28, 2014

doi:10.5539/jpl.v7n1p30 URL: http://dx.doi.org/10.5539/jpl.v7n1p30

\begin{abstract}
Many new diplomatic thoughts are reflected in the report of 18th National Congress of Communist Party of China (CPC). They are shown in the following aspects: "following the path of peaceful development unswervingly" moves towards "continuing to promote the lofty cause of peace and development", which embodies China will undertake more international responsibilities; China will strive to establish a new type of great power relationship which is of long-term stability and sound growth with other developed countries"; China will support the expansion of developing countries' representation and voice in international affairs and remain to be a reliable friend and sincere partner of other developing countries forever"; China will take solid measures to promote public diplomacy and cultural diplomacy, and safeguard China's overseas legitimate rights and interests. The new thoughts above will set a new tone of diplomatic strategies as well as policies and point the direction of China's diplomatic future development.
\end{abstract}

Keywords: CPC, the report of the 18th National Congress, new diplomatic thoughts

\section{Introduction}

The elaborations on China's diplomatic strategies and policies in the report of CPC's 18th National Congress have attracted much attention of the international community. This is directly related to China's future development in international society and China's attitude and international image presented in international arena. The diplomatic elaborations of the 18th National Congress reflect the new thoughts of China's diplomatic strategies.

\section{2. "Following the Path of Peaceful Development Unswervingly" Moves towards "Continuing to Promote the Lofty Cause of Peace and Development"}

The statement of diplomacy in the eleventh part of the 17th National Congress report of CPC is "following the path of peaceful development unswervingly" while the clear theme of diplomacy in the 18th National Congress report is "continuing to promote the lofty cause of peace and development". This change is not only the change of words, but also the profound change of strategic orientation. That is to say, China's strategic goal in diplomacy is to promote the lofty cause of peace and development. "Continuing to promote the lofty cause of peace and development of mankind" has become the central substance of this report, showing that China will be more actively involved in international affairs. "playing a responsible power role "shows the determination that China will play a more important part on future international stage and upgrade China's diplomatic mission to "promoting peace and development of mankind".

In the report of the 18th National Congress, China's diplomatic objective is "continuing to promote the lofty cause of peace and development of mankind", which is based on the profound changes in the current international situation and the development of China's comprehensive strength. The world today is undergoing profound and complex changes, but peace and development remain to be the underlying trends of times. The global trends toward multipolarity and economic globalization are deepening, cultural diversity is increasing, an information society is fast emerging, new breakthroughs are made in scientific and technological revolution, global cooperation is expanding at multiple levels and on all fronts, emerging market countries and developing countries are becoming powerful in overall strength, the balance of international forces is developing in favor of the maintenance of world peace, and all this has created more favorable conditions for ensuring general stability 
in international environment. On the other hand, the world is still far from being peaceful. This is the general overview of the current international situation. The world is developing deeply in the economic, political, cultural and other fields, making the world into a global village where you and I are interlocked and any country as a villager can't be separated from each other. Only when countries work together can they solve the existing problems in the development of human society and promote the cause of peace and development of mankind, so as to achieve a better vision of a harmonious world. As a responsible country, China is fully aware of the basic current situation of the social development and its role in the international society in this international background, thus China writes "continuing to promote the lofty cause of peace and development” into the CPC's report. The judgment and understanding of international situation made by CPC along with the willingness to make its own contribution to the peace and development of international community fully reflect China's style and role as a great responsible country. The complex changes in international situation and the sense of international responsibility have enabled China to regard "continuing to promote the lofty cause of peace and development of mankind" as its objective.

The improvement of national comprehensive strength and international status enable China to have the ability of "continuing to promote the peace and development of mankind". Since twenty-first Century, China has quickened its steps of reform and opening up and it has achieved more fruitful results in the process of modernization: the increasing national power, the improvement of people's living level, the growing international influence. Especially since 2010, China has surpassed Japan, becoming the world's second largest economy, which highlights China's strong economic capacity. In September 5, 2012, American comprehensive strategic research institutions, Rand Corporation announced the 2012 Blue Book of comprehensive national strength of major countries in the world, which shows that China has become the fifth comprehensive national power, ranking after America, Britain, France, Russia. American National Interests Committee once said, in 21st Century, China is a leading role who will not be motionless on international stage. Indeed, China is going toward the center of international stage, and it won't show no movement, but its movement is not a threat to neighboring countries as well as the world's peace and development. Instead, China's powerful comprehensive national strength and economic capacity will benefit the development of neighboring countries and the world. The combination of China's enhancement in comprehensive national strength and a strong sense of international responsibility make China be qualified to continue to promote the peace and development of mankind. Therefore, China has made a positive commitment that it will combine the benefits of Chinese people with the common interests of all peoples, participate in international affairs with a more positive attitude, play a responsible role, and cope with global challenges jointly.

China not only has the willingness and ability of continuing to promote the peace and development of mankind, but also in practice proves its diplomatic goals. China actively participates in international affairs and solves global problems in its development. Since the global financial crisis in 2008, China has strengthened consultation and communication with the developed countries, adopted financial restrictions actively, took a loose monetary policy and implemented structural tax cuts as well as the planning of industrial restructuring and revitalization, making efforts to alleviate the world 's financial crisis; In response to global climate change, China also has made an important contribution. According to the report of the United Nations Development Programme (UNDP), in order to prevent carbon emissions from rising to a dangerous level, we need to spend about $1.6 \%$ of the global GDP on that by 2030 . One of the main measures taken by China to tackle climate change was the large-scale afforestation; the development of low-carbon economy was also an important measure taken by China in response to climate change; In addition, China participated in the formulation of major international rules, making a contribution to a green world. For example, China participated in international climate negotiations to tackle climate change. It is the first time that China has actively participated in the formulation of major international rules; China also made a commitment of carbon emissions reduction and harmonious development. According to the relevant provisions of "the United Nations Framework Convention on Climate Change" and "Kyoto Protocol", China will make a greater contribution to international cooperation on climate change, adhering to the principle of common but differentiated responsibilities.

China will continue to work hard to hold high the banner of peace, development, cooperation, mutual benefit and strive to maintain world peace and promote common development. Compared with the report of the 17th National Congress, the "win-win" concept is also an important way to promote the lofty cause of peace and development of mankind, which is one of the innovations

In 1956, Mao Zedong predicted China’s world position: "In the twenty-first Century, China will make a greater contribution to mankind". (Note 1) CPC makes it clear in the report of the 18th National Congress that "we are willing to work with people of all other countries for the lofty cause of peace and development and make 
unremitting efforts”. Today, China plays a responsible role, and promotes peace and development of human society, which is the general trend.

\section{China Will Strive to Establish a New Type of Great Power Relationship}

The report of the 18th National Congress of CPC clearly points out that "we will improve and develop the relationship with developed countries by broadening areas of cooperation, properly handling differences, and we will strive to establish a new type of relationship which is of long-term stability and sound growth with other major countries.” The documents demonstrate China will establish a new relationship between great powers with the western developed countries, which is one of the innovations. New relationship with great powers refers to the relationship with the western developed capitalist countries, especially America.

The relationship between great powers is the mainstream of the development of international relations in today's international society and its development directly affects the fate of the world. Which kind of strategy countries adopt, namely unilateralism, selective contact, coordination of multilateralism, directly relates to the future development of international community. The report of the 18th National Congress, defines China's diplomacy as committing to creating a new, long-term, stable, healthy relationship with the western developed countries. This is a new contribution to the orderly development of world politics and a way of promoting the democratization of international relations. At the same time, a pressing matter of China's diplomatic development is constructing the new relationship with great powers.

China has a profound understanding of establishing a new, long-term, stable and healthily developed relationship with other major powers. In December, 2005, China's foreign scholar Gong Li pointed out that one of the international strategic orientation of China's peaceful rise is committing to establishing a new, non-alignment, non-confrontation, and non-targeting at any third party and constructive relationship with other major powers. In February, 2012, Xi Jinping paid a visit to America and made a theme speech of creating a better tomorrow of a cooperative partnership between China and America, pointing out that "promoting the cooperative partnership between China and America to make more new progress, and making efforts to transform the partnership between the two countries into a new type of relationship between major countries in twenty-first century". In April 30th, China's international studies expert Qin Hong published an article titled China and America need to make efforts to build a new type of relationship in the overseas edition of "People's Daily", pointing out that "building the new type of relationship between China and America into a great cause". In May 3rd, Hu Jintao made a speech on "promoting the mutually beneficial and win-win cooperation, developing new relationship between great powers" at the opening ceremony of the fourth round of Sino-US strategic and economic dialogue speech, pointing out that "The development of the new relationship between China and America needs creative thinking, trust between each other, equality and mutual understanding, positive action, the cultivation of friendship". These all reflect that the thread of the new relationship between China and America is getting more and more distinct, outline clearer, content more and more abundant. On the same day, Xi Jinping met the special representative of President Obama, Secretary of State Hilllary Clinton and Finance Minister Geithner at the fourth round of Sino-US strategic and economic dialogue, pointing out "as two powers, China and America are different in political system, historical and cultural background, levels of economic development .Building the new type of relationship requires the determination and confidence of 'He who does not reach the great wall is not a true man' and the patience and wisdom of "crossing the river by touching the stones' ". In November 7th, Obama succeeded America president, Hu Jintao sent a message of congratulation, saying: "You and I have reached a consensus on building a win-win partnership of mutual respect, mutual benefit, and exploring the construction of new power relationship”. CPC and Chinese government have laid the foundation of China's future diplomatic direction in the exploration and construction of new power relationship. The report of the 18th National Congress put it into the party's documents, which is the unique innovation.

The connotation of new type of great power relationship, namely "innovative thinking, mutual trust, equality and mutual understanding, positive action, cultivating friendship", is also the main tone and the melody of future relationship between great powers. After the end of the Cold War, especially since the twenty-first Century, the relationship between great powers can not follow and use the traditional thinking of cold war, "China is not the Soviet Union", international community is not the law of the jungle and the so-called "zero sum game", so we must create new thinking, emancipate mind and seek to live together and benefit from each other mutually in the process of developing relationship between great powers, which is the inevitable trend. Mutual trust is the basis of the benign development, international relationship must establish mutual trust mechanism to effectively solve the contradiction and seek the new development path. Only by mutual trust can we promote peace, development, cooperation and the win-win situation effectively in the new relationship between great powers. Equality and mutual understanding is the premise of new type of great power relationship. Although great powers are different 
in historical and cultural traditions, social system, economic system, they are equal and independent. Because of the different national conditions, countries should understand each other, seek common ground while reserve differences in international affairs, rather than trump others. Positive action is the path and measures to establish the new type of great power relationship. Any great power should continue to pursue peace and development of mankind. When faced with contradiction, the two sides should strengthen communication and coordination to solve problems jointly. In response to global problems, great powers need to work together positively to meet the challenges brought by globalization. Cultivating friendship is the way, purpose and destination of developing new type of great power relationship. On one hand, we can promote the benign development through friendly development of nongovernmental diplomacy. On the other hand, the development of relationship between great powers must eventually return to friendly contacts between governments, political parties and people. Only by a profound friendship between each other can our "global village" form a harmonious world, and peace and development of mankind will come true.

In the current relationship of great powers, establishing new relationship between great powers is not only the sole choice, but also China's diplomatic tone. Under the current situation, we are facing a series of contradictions and problems in the process of constructing relationship with developed countries, only by strengthening coordination and cooperation between countries can we promote the development of relationship between great powers. Sino-US relationship is primary in building a new great power relationship. On the Diaoyu Islands, Huangyan islands and other issues, China actively seek consultation and communication with America. How America solves these problems is directly related to the construction of the new type relationship.

\section{China Will Support the Expansion of Developing Countries' Representation and Voice}

Compared with the report of the 17th National Congress, the 18th National Congress adds "supporting the expansion of developing countries' representation and voice in international affairs, remaining to be a reliable friend and sincere partner of other developing countries forever" in dealing with the relationship of developing countries. This expression reflects that the CPC requires to enhance the status and role of developing countries in international affairs, increase the discourse right of developing countries in international society, and change the development situation of "Strong North and Weak South" in international system. At the same time, China positions itself as the reliable friend and partner of developing countries forever.

The documents of the Party point out that China supports the expansion of developing countries' representation and voice in international affairs and remains to be a reliable friend and sincere partner with developing countries forever, which is based on China's role position of itself, and is the reflection of a responsible country. China positions itself as a developing country, the relationship between China and other developing countries is defined as the basis of China's foreign policy. China will always stand together with the vast number of developing countries, experience the same fate, maintain the solidarity and interests of the developing countries, and promote the improvement of the status of developing countries. With China's peaceful development, China will undertake more international responsibilities, which inevitably includes the promotion of developing countries in international affairs and representative voice in international community as well as the enhancement of developing countries' overall strength. China is also taking the international responsibility of its own. As for the reform of the United Nations, China supports developing countries to have access to the Security Council and requests priority to increase the representation of developing countries. While developing countries accounts for $2 / 3$ of the total membership of the United Nations or more, representation in the Council is in serious shortage. China advocates that we should allow more countries, especially small countries to have more opportunities to take turns to enter the Security Council, to participate in decision-making. Since the 2008 financial crisis, China calls for the strengthening of financial supervision cooperation, pushes forward the reform of international financial organizations, improves the representation and voice of developing countries in international financial organizations and increases the voting rights of developing countries in International Monetary Fund.

Today's world is a diverse world. International affairs must not be monopolized and ruled by developed countries, we need to increase the voice and say of developing countries in international society. Developing countries must change the situation of being marginalized in international system. China always supports the participation of developing countries in international affairs and strengthens their components and discourse right in international system. China supports developing countries to participate in the formulation of international system rules, institutions as well as mechanisms and to change the development process of international system which is controlled by developed countries. China supports developing countries to expand voice in international affairs, tries to gradually change the current international system which is completely dominated by Western powers, draws up international mechanisms which are beneficial to developing countries increases their voice in world 
affairs, and changes the great disparity of power between the north and the south, thus to eliminate the old international political and economic order and promote equality and democratization of international relationship. In March, 2012, Hu Jintao delivered an important speech which stresses that China will stand with developing countries through storm and stress in the meeting with the leaders of the BRIC countries and increase the representation and voice of developing countries and emerging market countries. In October, China's deputy permanent representative to the United Nations, Wang Min pointed out that the reform of United Nations in international affairs should increase the voice of developing countries in the discussion of the annual report in United Nations General Assembly. China will always be the reliable friend and sincere partner of other developing countries, which is the exact location of the relationship between China and other developing countries. Whether China is poor in the past or the strong power which is going toward the prosperity now, developing countries have always been the reliable friend and the most sincere partner of China. Establishing the relationship between China and developing countries in the form of CPC's report helps promote the deep friendship and cooperation. China itself is the largest developing country, which is the basic starting point of our foreign policy. China's development is inseparable from the cooperation of developing countries. They both have many symbiotic interests in international affairs, will support each other to become staunchest friends in international system.

\section{China Will Take Solid Measures to Promote Public Diplomacy and Cultural Diplomacy, and Safeguard China's Overseas Legitimate Rights and Interests}

Compared with the report of CPC's 17th National Congress, the report of the 18th says that we will push forward the public and cultural diplomacy, safeguard the legitimate rights and interests overseas.It highlights that China attaches great importance to public diplomacy and cultural diplomacy, The CPC has become increasingly aware of the importance of "soft power", and China's overseas rights protection has become an important part of China's national interests.

Since the twenty-first Century, public diplomacy has become a new growth and focused point in China's diplomatic work, its position and role have improved in the overall diplomacy and its importance has become increasingly prominent. Public diplomacy is the objective requirement of improving China's diplomatic layout in the new situation, and an important development direction of our diplomatic work. Public diplomacy is usually dominated by the government, and we need to introduce the national conditions and policy ideas to the domestic and foreign public by various means of transmission and communication in order to obtain public understanding, recognition and support, gain the popular opinion, build up a good image of the government and political parties, create a favorable public opinion environment and promote the national fundamental interests. The construction of soft power which regards the value idea, system, politics, cultural influence as the core contents is increasingly attracting great attention of countries, especially major powers. Public diplomacy is an important carrier of the construction of soft power, and countries should vigorously carry out public diplomacy, build a comprehensive national soft power. We need to enhance China's international attraction, influence and charisma further, at the same time make people more comprehensively understand the world and themselves. It Is not only an urgent task, but also a long-term strategy. (Note 2) Public diplomacy is an important way to develop China's soft power. China not only deepens the construction of public diplomacy in theory, but also continues to expand its depth and breadth in practice. Through public diplomacy, we can propagate and promote China's political system, value proposition, social thought and value system, to let the world know a real China and eliminate prejudice, misunderstanding and suspicion of China held by some countries in the world. China continues to promote public diplomacy in practice, the Beijing Olympic Games, the Shanghai World Expo, the Guangzhou Asian Games have reflected the development of China's public diplomacy and created a good international image and concept of development.

The report of the 18th National Congress points out that our country should develop vigorously the cultural diplomacy, promote the construction of China's soft power. In October, 2008, Foreign Minister Yang Jiechi made a report entitled "the international situation and diplomatic work after Olympic Games" at the Party School of the CPC Central Committee, in which the concept of "cultural diplomacy" is first clearly put forward. He thought, "the Olympics is a focused dialogue and intersection between east and west culture, humanistic Olympic Games is one of the core concepts of the Beijing Olympic Games. Promoting vigorously cultural diplomacy, enhancing mutual communication and friendship between people and nations are more important for promoting peace, prosperity, trust cooperation between countries than any time before". With the development of globalization and informatization, international exchange and communication enhance the strategic importance of international cultural exchanges. Countries launch a fierce competition in the humanities, regard the humanities diplomacy as an important part of national foreign strategy and promote the development of national 
soft power. As for connotation, Cultural diplomacy includes ideological diplomacy, civil diplomacy and people to people diplomacy. Ideological diplomacy focuses on the exchange and propagation of ideas and values. Civil diplomacy bases itself on communication and propagation of literature, art, science. People to people diplomacy mainly relates to universal communication. China sets up Confucius Institute in the world, sets off a wave of Chinese learning, disseminates traditional Chinese culture, strengthens educational culture exchanges and cooperation between China and other countries, and expands the space of China's diplomatic activities.

With the increasing prosperity of China's comprehensive national strength, the connotation and extension of national interest are gradually expanding. Maintaining legitimate rights and interests of citizen and legal person overseas effectively has become an important part of China's "Citizen Diplomacy". Writing "safeguarding the lawful rights and interests of Chinese overseas" into the CPC's report reflects that CPC attaches great importance to Chinese citizens' security and protection of legitimate rights and interests overseas, reflects that the diplomacy of "people-oriented" and "for the people", and shows that diplomacy has entered the "people-oriented era". The lawful rights and interests overseas are important parts of China's national interests, and an overseas extension of national interests. In recent years, the security of Chinese workers overseas is threatened, Chinese people are arrested and shot by other countries' policeman, Chinese investment and energy interests overseas are infringed, which make CPC and the Chinese government pay more attention to the maintenance of legitimate rights and interests overseas.

As Hu Jintao said at the eleventh meeting for Chinese diplomats, we would need to strengthen public diplomacy and cultural diplomacy, carry out various forms of cultural exchange activities, and make solid dissemination of Chinese culture. We must adhere to principle of people-centered approach, protect the lawful rights and interests of our citizens and legal persons overseas, maintain the legitimate rights and interests of the Hong Kong Special Administrative Region, the Macao Special Administrative Region and Taiwan compatriots. (Note 3)The report of the 18th National Congress points out that we need to promote the development of China's public diplomacy and cultural diplomacy, promote the construction and upgrading of China's soft power and ensure the effective guarantee of the lawful rights and interests of Chinese overseas in order to get the new direction and new beacon for the future development of China's diplomacy.

\section{Conclusion}

The presentation of diplomacy in the 18th National Congress of CPC's report shows the new thoughts of China's diplomatic development. These mainly cover the external goal of China's diplomacy, the new great power relationship between China and developed countries, friendship and partnership between China and developing countries, China's soft power diplomacy, the maintenance of Chinese overseas and the legitimate rights and interests. The provisions of China's diplomacy in CPC's documents set the tone for the development of China's diplomacy and point out the development direction of China's diplomacy.

\section{References}

Hu, J. T. (2012). Making progress unswervingly along the path of socialism with Chinese characteristics, striving to build a well-off society in an all-round way. People's Press.

Yan, S. H. (2012). Interpretations of several creative judgments of CPC's $18^{\text {th }}$ Report. People's Tribune, 33.

Tutoring reading of CPC's $18^{\text {th }}$ Report. (2012). People's Press.

Ruan, Z. Z. (2012). Interpretations of CPC's $18^{\text {th }}$ Report: China is showing new diplomatic vision. People's Daily (Overseas Edition), November $29^{\text {th }}, 2012$.

Li, H. L. (2013). The new thinking of diplomatic strategy in CPC's $18^{\text {th }}$ Report. Journal of Wuhan University of Science and Technology (social science edition), 6.

Yu, S. (n. d.). Holding world situation and showing diplomatic strategy. Contemporary World, 1.

\section{Notes}

Note 1. “Mao Zedong's collected works”, Vol. 7, People’s Press, published in 1999, p. 157.

Note 2. Yang Jiechi, “Efforts to develop a new situation of public diplomacy with Chinese characteristics”, Qiushi Journal, 2011(4), pp. 43-46.

Note 3. Hu Jintao and other central leaders attend the $11^{\text {th }}$ meeting of diplomatic envoys, Retrieved from http://news.xinhuanet.com/politics/2009-07/20/content_11740850_1.htm 


\section{Copyrights}

Copyright for this article is retained by the author(s), with first publication rights granted to the journal.

This is an open-access article distributed under the terms and conditions of the Creative Commons Attribution license (http://creativecommons.org/licenses/by/3.0/). 